INFORMAATIOTUTKIMUKSEN PÄIVÄT 2020

\title{
Informaatiotutkimuksenkin historialliset yms. 'käänteet' ja käsitys ihmistiedosta ja -ymmärryksestä Gabriel Naudélla
}

\author{
Vesa Suominen \\ Oulun yliopisto \\ Sohveli2012@gmail.com \\ https://orcid.org/0000-0001-8899-1133
}

Asiasanat: Naudé, Gabriel; kirjastohistoria; aatehistoria; historiankirjoitus; historianfilosofia

Informaatiotutkimuksessakin on viime vuosikymmeninä esitetty näkemyksiä siitä, että tietomme rakentuu aivan perustavalla tasolla yhteisöllisesti, erilaisissa käytännöissä, rakenteissa ja kielessä ja viime kädessä historiallisesti (ks. esim. Benediktsson 1989 ja Talja, Tuominen \& Savolainen 2005) Yllättävästi saattaisimme löytää erityisesti tiedon historiallisuusulottuvuuteen liittyviä aineksia ranskalaiselta 1600-luvun libertiiniltä ja kirjastonhoitajalta, Gabriel Naudélta (1600-1653).

Artikkeli on lisensoitu Creative Commons Nimeä-EiKaupallinen-JaaSamoin 4.o Kansainvälinen -lisenssillä 
Erotuksena aikansa rationalistiseen filosofiaan Naudéta luonnehditaan ilmaisuin humanistinen ja historiallisfilologinen (ks. esim. Lemke 1991). Robert Damienin $(1995,235)$ kuvaa Naudén "keskeistä kokemusta" eräänlaisena epätoivona ja tajuna "kaiken mahdollisesta tuhoutumisesta", minkä "Naudé on kokenut ja todennut sen niin uskonnon kuin tieteen, niin politiikan kuin luonnonkin suhteen.” Jäljelle jää vain alati muuttuva historia ja voisimmekin käsittää naudélaisen kirjaston valtavaksi historiografiaksi varhaismodernin tacitismin alkuvaiheen (ks. Soll 2003) hengessä, mihin tässä keskityn.

Joseph Mali (1989) kytkee nykyiseenkin keskusteluun hieman alle sata vuotta Naudén jälkeen vaikuttaneen "italialaisen Hegelin" (Ježić 2015, 243), Giambattista Vicon (1668-1744). Itse hartaana katolilaisena Vico (1744/2015, 17-) universalisoi teoriansa yli kristillisen ajattelun rajojen tarkoituksellisen myyttisellä kuvauksellaan siitä, miten uskonnon, avioliiton ja kuolleiden hautaamisen perusinstituutiot syntyvät vedenpaisumuksen jälkeen yhteyden hebrealaiseen uskoon menettäneiden Noan jälkeläisten keskuudessa. Antropologiseen tapaan hän sitten esittää, miten sekä nuo perusinstituutiot että muut, puhtaasti ihmisten historiasta syntyvät instituutiot niihin liittyvine hyveineen muodostuvat historiassa toisiaan seuraavien vaiheiden (l'Età degli Dei / eroi / uomini) kautta (mikä tosin oli toistuvaa korruption takia).

Vicon yhteydessä verum-factum-käsite tarkoittaa, että tietää ja käsittää voi vain sen, minkä on itse tehnyt. Niinpä ihmisellä ei oikeastaan voi olla tiedettä Jumalan luomasta luonnosta, mutta kylläkin ihmisten omaa tekoa olevasta historiasta ja yhteiskunnasta. Traditio olisi ikään kuin yhteinen projekti, jossa pohdintaan osallistuvat niin elossa vielä olevat kuin heidän edeltäjänsäkin. Tämä olisi ehtona sillekin, että voimme ylimalkaan puhua traditiosta (Mali 1989), eikä kyse olisi enää pelkästä ilmenneiden ajatustapojen sosiologistisesta kuvauksesta.

Varhaisempi, mutta 1600-luvuillakin protestanttisen sola scriptura -teesin vuoksi ajankohteinen oli katolisen kirkon Tradition apostolica -oppi. Raamatun lisäksi kristillisyys tarvitsee sen innoittamaa inhimillistä järjenkäyttöä, tulkintaa ja soveltamista (Mali 1989 ja Concilium de Trento 1566/1833).

Mali jakaa tapoja nojata historiaan ja traditioon yhtäältä kriittiseen traditioon, toisaalta konservatiiviseksi luonnehdittavaan vallitsevien olojen ja usein etuoikeuksien perusteluu historian avulla. Voisimme myös puhua nämä molemmat kattaen konstitutiivisesta traditiosta ja historiasta. Naudén käsitystä kuvaamaan ei konstitutiivisen historian ja tradition käsite oikein soveltune. Tässä keskeistä on (erityisesti politiikan) moraalin perusta konstituutiossa. 
Monessa suhteessa Naudé edusti poikkeuksellisen radikaalilla tavalla hänen aikaansa muutoinkin leimaavaa moraalisen argumentaation notkahdusta politiikan teoriassa. Aivan katkoksesta ei ole kyse, koska esimerkiksi perustaltaan uskonnolliset ideat samoin kuin luonnonoikeus, sopimusteoriat jne. elivät tuolloinkin ainakin siinä, mitä oli sopivaa sanoa tai kirjoittaa julkisesti. Traditio apostolicassa kehkeytynyt politiikkaakin koskeva moraali saattoi kuitenkin olla Naudéllle ja valtion säilyttämistä ajatellen vain tarpeeton rasite. Tässäkin Naudé Jean-Pierre Cavaillén (2006) sanoin ehkä "huolehti kovasti, että hän menee pidemmälle" kuin muut, mikä tavoittanee jotain Naudén luonteestakin.

Osana Naudén epätoivoa olivat epäilemättä hugenottisotien (1562-1598) traumat. Luontevaksi kävi politiikan ymmärtäminen ensisijaisesti valtion olemassaolon turvaamisena, koska valtio olisi ainoa, vaikka sekin hauras toivo (Damien 1995, 202-203). Naudélla $(1633 / 1641,54)$ vallankäyttö (admistration politique) näyttäytyykin valtiota vahvistavana 'insinöörityönä'. Naudé (1633/1641, 40 ja Damien 1995) kiittelee Jean Bodinia (1530-1596) moraaliihanteiden ja Jumalan tahdon syrjäyttämisestä politiikan lähtökohtina. Yleisemminkin Naudélle $(1625,73)$ mekaniikka oli tieteenä erityisen ideaalinen.

Paremminkin olisi kyse historian käsittämisestä kumuloituvaksi kokemukseksi ja eräänlaiseksi vallan käytön ja menestyksekkäiden poliittisten operaatioiden mallikirjaksi, mikä on ollut tavanomaista Naudén jälkeisessäkin ajassa. Voisimme sanoa, että Naudélle ei traditiota sanan varsinaisessa mielessä ollut olemassakaan, vaikka historia olikin hänelle toisella tavoin merkityksellinen.

Ajatus naudélaisesta kirjastosta jonkinlaisena yhteisen rationaalisuuden kenttänä, respublicana literariana (Damien 1995, 57) saattaisi komplisoida asiaa. Siinäkin pitäisi ehkä kuitenkin ajatella itse syntyvää tietoa ja ymmärrystä luonteeltaan tekniseksi, jolloin myös sen mahdollisesti historiallisyhteisöllinen konstituutiokin voisi olla pelkistyneempi ja merkitys rajoittuneempi.

\section{Lähteet}

Benediktsson, D. (1989). Hermeneutics, dimensions toward LIS thinking. Library and Information Science Research, 1989(3): 210-34.

Cavaillé J.-P. (2006). Naudé, la prudence extraordinaire du coup d’État. Des fins de la prudence dans la France des XVIe et XVIIe siècles, revue en ligne Comètes, avril 2006. (https: //journals.openedition.org/dossiersgrihl/4807. Viitattu 17.8.2020).

Concilium de Trento (1566/1833). The Cathesm of the Council of Trent. Baltimore: Myers.

Damien, R. (1995). Bibliothèque et État. Presses Universitaires de France.

Damien, R. (2006). Gabriel Naudé (1600-1653) et la révolution bibliothécaire du savoir. Contemporaine $2006 / 2\left(\mathrm{~N}^{\circ} 82\right), 18-23$. 
Ježić, L.F. (2015). Viewing Vico within German Idealism. Philosophica, 60 (2/2015), 243-250.

Lemke (1991). Gabriel Naude and the Ideal Library. Syracuse University Library Associates Courier, 26(1), 27-44.

Mali, J. (1989). Science, Tradition, and the Science of Tradition. Science in Context, 3(1), 143-173.

Naudé, G. (1625). Apologie pour tovs les grands personnages qui ont elle fauffemcnt foupçonncz de magie. Paris: Targa.

Naudé, G. (1633/1641). Bibliographie politiqve. Paris: Qvillavme Ele.

Soll, J. (2003). Empirical History and the Transformation of Political Criticism in France from Bodin to Bayle. Journal of the History of Ideas, 64(2), 297-316. https://doi.org/10.1353/ jhi.2003.0030

Talja, S., Tuominen, K., \& Savolainen, R. (2005). "Isms" in information science: constructivism, collectivism and constructionism. Journal of Documentation, 61(1), 79-101. https://doi. org/10.1108/00220410510578023

Vico, G. (1744/2015). La Scienza nuova 1744. Laboratorio dell'ISPF. doi: 10.12862/ispf15L101 